\title{
PRACTICES AND CHALLENGES OF CONTINUOUS ASSESSMENT IN COLLEGES OF TEACHERS' EDUCATION IN THE WEST OROMIA REGION, ETHIOPIA
}

\author{
Gemachu Oli, Teklu Tafase Olkaba
}

\begin{abstract}
The main purpose of this study was to investigate the practices and challenges of continuous assessn th in leges of teachers' education in the western Oromia region. For this study, the researchers selected thres colleges teachers' education, purposely based on job experience. The researchers selected Nekemte, I embi ol $\mathbf{r}$ and Shambo colleges teachers' education from well, medium, lower experienced respectively. Descr tive s vey design involving both qualitative and quantitative approaches was employed. 134 student teachers were selected and participated in the study. The quantitative data was collectea rou the questionnaire and observation checklist and analyzed using frequency and percentage, whe an the litative data interview and document analysis were analyzed using narrative form and interpre tiv study revealed that the extent of practicing continuous assessment in class ive he udy also showed that teachers have positive perception toward continuous assessment and they ccepte tcontinuous assessment as important to improve the achievement of learners. The finding disclesed at large class size, shortage of time, teachers' work load, low interest of students, large instructional con 't, a lacn of commitment among teachers as the major factors are hindering the practice of continuous ass vmen in colleges of teachers' education.The researchers recommend that educational authorities n stoc, otw rs should make effort to a manageable number ofstudents' per class, College administrators shoula llow achers to cover the minimum workload than over loading above the standard, set for college of teache. 'ea rion
\end{abstract}

Keywords: Continuous Assessment, College Students, Colleg Teachers'Education, Evaluation, Standardized testing

\section{Introduction}

Since the endorsement of 1994 Ethio ian eaucation and training policy, different teac er ining models have been introduced to improve the ur tit nd quality of teachers that, in turn, brings $t^{\prime}$ - quali education as a whole. The impetus of achil $y$ and aching profession is to bring up and sha ing en atio s in the world of profession, impacting th na, n development. In line with this argument $F$ - via ducation and training policy of 1994 artich $3.4 \mathrm{w}$ h sub-articles $4.3 .1 ; 3.4 .3$ \& 3.4.5 and artich 3.6 ub-a icle 3.6.2 states about teacher and teacher educa on, spectively, as:

Aso rtain mat teucher trainees have the ability, gence, rot onal interest, and physical and mental ness, app priate for the profession.

Te cher education and training components will en asize basic knowledge and professional code of ethics,

- A professional career structure will be developed in respect to the professional development of teachers.

- The participation of teachers and researchers in getting the necessary field experience in various development and service institutions and professionals of such institutions in teaching will be facilitated [1].

According to the education and training policy of Ethiopia [1], the efforts, designed to make teachers and teaching profession at the highest ladder tip, was well
Copyright (C) 2020, Gemachu Oli, Teklu Tafase Olkaba. CC BY license (http://creativecommons.org/licenses/by/4.0).

articulated in the policy document. According to the teacher training policy document, continuous assessment is the pillar of the teacher training policy to translate the notion of active learning methods into practice that realize the potential of students and the quality of education at all levels. To achieve effective education in one country, continuous assessment is important. Assessment is one of elements of the instructional process that plays an important role to improve learning in educational institutions.

As stated in Educational and Training Police [2], the practical task of implementing the new curriculum at the school level requires continuous assessment as part of the curriculum in general and the instructional process in particular. To understand this, the role of teachers is of paramount importance. In other words, teachers should be well informed about the concept and procedures of practicing continuous assessment before they implement it. In relation to this, [3-5] suggested that teachers' knowledge and attitude should be considered for the effective practice of the assessment program. The educational progress of learners needs frequent assessment. The various aspects of learning activities of learners should be assessed by various methods. The traditional assessment method mainly focuses on testing which encourages superficial learning, but did not assess the wider skills of pupils. Thus, continuous assessment should be essential to measure learners' performance in a holistic 
manner. As the researchers are college teachers they observed from their experience that there were problems, related using varieties of continuous assessment techniques in college.

Continuous assessment is a typical classroom based strategy which provides regular information about the teaching-learning process. Concerning this, [6, 7] suggested that continuous assessment is practiced on a day to day basis to judge the quality of the individual's work or performance. Employing continuous assessment enables a teacher to assess more of the intended behavior of students and to take note of factors, such as their active participation, how articulate they are, their relationships with others and their motivation that have a high educational relevance [8,9]. Continuous assessment is a student evaluation system that operates at a classroom level and is integrated with the instructional process.

So far, many researchers conducted different studies on the problem in different ways. For instance, [10] conducted the study on assessment of the implementation of continuous assessment and found that the majority of teachers on continuous assessment practices were not well understood, the objectives behind the important of continuous assessment were not clear to most teachers. Yet few who were aware did not practice, and a field work and project were not commonly applied. These are other reasons that initiated the researchers to undertake the study. Therefore, the main aim of this study was to investigate the practices and challenges of continuous assessment in colleges of teachers' education in the western Oromia region, Ethiopia. The specific objectives of the study were

- To identify the perception of teacher ard continuous assessment in Colleges of Teacher E Fuc tion in the West Oromia region.

- To find out the extent of the teache, continuous assessment practice in Colleges o 16 hers Education in the West Oromia region.

- To identify the major f cors $t$ ifluences the practice of continuous as essm nt in olleges of Teachers' Education in the $k$ st $Q$ om res on.

\section{The Conc and of the Study}

Many scho s wro about the definition of assessment in differe wa $\mathrm{R}$ garding this, [11] state that the term assessment ay used in education to refer to any procedure on ctivit hat is designed to collect information a at the nou se, attitudes, or skills of a learner or a sup of le ners". They also stated that "assessment is a pro ss of taining information that is used to make an educa decision about students, to give feedback to the students about his or her progress, strengths and weakness or to judge instructional effectiveness and circular adequacy and to inform the policy". Again according to [3, 12-14], assessment is any act of interpreting information about students' performance, collected through any of multitude of means or practice. It is the procedure, through which information about pupils is obtained by any method or procedure that is formally or informally.

Assessment is broader than testing and measurement, because it includes all kind of ways to sample and observe students' skills (psychomotor domain), knowledge (cognitive domain), values and emotions (affective domain). People often equate assessment with tests, measurement and evaluation [15]. Assessment, however, is quite different in concept. According to [1618], measurement involves the assigning of members to represent the amount of something, possessed by an objective event or system. Students are doing in terms of specific objectives. Tests are used for summative evaluation. Tests are embedded in the curriculum materials, provided they match the specified learning outcomes. Tests, the teacher creates, are aligned with the ning outcomes. Teachers can use a test to help stud its us g assessment procedures as teaching tools. Often, a test can be used for controlling students' behavio and om unicating achievement expectations from a udent 9, 20].

\subsection{Assessment Paradigı}

The growing current atur dentify four assessment paradigms of clas roo $n$ ssessment that can be used in conjunction with $\mathrm{e}$ ther: assessment for learning, assessment s learnitro, assessment of learning and assessment in lear ing [2].

Assess ent or cearning: is an ongoing, diagnostic and schoo bas 1 process that uses a variety of assess r too to sess learner's performances [22]. It reflects à view f learning, in which assessment helps studen lea wetter, rather than just achieve a better $\mathrm{n} r \mathrm{rk}$, in ves formal and informal assessment activities o to learning and to inform the planning of future le. ning, includes clear goals for the learning activity, pro ides the effective feedback that motivates a learner Id can lead to improvement, reflects a belief that all st lents can improve, encourages self-assessment and peer assessment as part of the regular classroom routines, involves teachers, students and parents reflecting on evidences, and is inclusive for all learners.

Assessment as Learning: occurs when students are their own assessors. Students monitor their own learning, ask questions and use a range of strategies to decide what they know and can do, and how to use assessment information for new learning. Assessment as learning: encourages students to take responsibility for their own learning, requires students to ask questions about their learning, involves teachers and students creating learning goals to encourage growth and development, provides ways for students to use formal and informal feedback and self-assessment to help them understand the next steps in learning and encourage peer assessment, self-assessment and reflection.

Assessment of Learning: assists teachers in using evidences of students' learning to assess achievements against outcomes and standards. In this assessment paradigm, the teacher directedness is paramount and the student one has little involvement. Sometimes referred to as 'summative assessment', it usually occurs at defined key points during a teaching work or at the end of a unit, term or semester, and may be used to rank or grade students. The effectiveness of assessment of learning for grading or ranking purposes depends on the validity, reliability and weighting, placed on any one task. This implies that there are teachers, who design learning and collecting 
evidences to decide what has been learnt and what has not particularly at the end of instruction.

Assessment in learning: it places question at the center of teaching and learning. It deflects teaching from its focus on a 'correct answer' to the focus on a 'fertile question'. Through inquiry, students engage in processes that generate feedback of their learning, which come from multiple sources and activities [23, 24]. It contributes to construction of other learning activities, lines of enquiry and generations of other questions. Students are at center of learning, monitor, assess, and reflect on learning and initiate demonstration of learning (to self and others).

Besides, teacher plays a role as coach and mentor in this model. Moreover, teachers and students need to understand the purpose of each assessment strategy, so that the overall assessment 'package', being used by learners and teachers, accurately capture and use meaningful learning information to generate deep learning and understanding.

\subsection{Assessment Methods}

The Portfolio Assessment: it must be more than just a collection of student work to give a full picture of what a learner has achieved [25]. It has also stated, that portfolio based assessment is an important means of individualized, student-centered evaluation. Portfolio assessment has the potential to improve the complex task of student assessment [26]. More specifically, portfolios are essentially different from other forms of assessment in that they make it possible to document the unfolding process of teaching and learning over time. In relation to this [6] stated portfolios as a collaborative assessment, partly determined by a classroom teacher and pa y a learner. As [18] pointed out, portfolio assess en is a new trend to make authentic assessmen, erta ing 0 students' performance or product in classroon

Self-assessment: Given the $c^{\prime}$ anc studuits can assess themselves quite accurately, - ta d p [27]. Supporting this idea, [25] suggeste curt se E-o praisal exercises are likely to increwse th moti ation of learners. Thus, self-assessment as impact on active learning to the extent of liza on that students have the ultimate responsibili th own learning. It can help students to pinpo theil strength and weaknesses and find ways of in rov nent 28].

Peer Asse me - Students are encouraged to assess on ar's 1 arning and understanding, taking resibilh fo pporting their classmates and making agress to ther. In light of this, [25] put the idea of pec asses hent as a response in some form to other learne. Nork. It can be given by a group or an individual and it can take any of a variety of assessment techniques.

Projects: can be given individually or in groups to encourage students to become active and independent learners. Whether projects are used early or late in the course, the time that is needed must be time, tabled for students as well as for teachers [29]. They further stated that projects encourage students to work together and reflect their work. Furthermore, [30] asserted that projects are important to show the attitude, skills, knowledge and the learning process of students as they engage in activities.

Interviews and Conferences: Teacher-student interviews or conferences are productive means of assessing individual achievements and needs. It is stated, that during discussions, teachers can discover students' perceptions of their own processes and products of learning [30]. According to [31], interviewing is one of the best ways to find out how much children have learned and how well they understand what they have learned. Conferences can be used more widely as part of the assessment and may take the form of discussion between teach and students about schoolwork [32]. As [32]; and [3 pols d out, interviews and conferences are truly authenti vays of obtaining information about learners' as nevo en and their thinking. To attain this, opon-end $d$ and partially structured questions can be used

Quizzes, Tests and Exa, natio s: are parts of the traditional mode of asses nt. "hey are most often used for assessing students' kno a dge of content; nevertheless, they may be und for ass ssing processes skills and attitudes [33]. A cording [34], quizzes, tests and examinations are us as ssessment mechanisms in combination th a rnawn methods of assessment these days. This sho th paper and pencil tests and alternative ne noa of ssessment complement each other. This ena s a te cher to have detailed, valid and reliable inform tion at students and the teaching learning proc s. Mo often, quizzes and tests are part of the contin1ou. asse sment and examinations are part of the summ. ive assessment.

Continuous Assessment: is a more formative rans of assessing learners that gives an opportunity for th $m$ to improve their performance. It is used as a process of gathering and integrating information about learners' shifting from a judgmental role to a developmental role [25]. Continuous Assessment is carried out at periodic intervals for the purpose of improving the overall performances of learners and of the teaching/learning process [35].

Defined continuous assessment as a mechanism which shows the full range of sources and makes teachers to gather, interpret and synthesize information about learners [16]. Continuous assessment of the learners' progress could be defined as a mechanism whereby the final grading of learners in the cognitive, affective and psychomotor domains of learning systematically takes account of all their performances during a given period of schooling.

Other definitions $[16,36]$ describe continuous assessment as an assessment approach which should depict the full range of sources and methods, teachers use to gather, interpret and synthesize information about learners; information that is used to help teachers understand their learners, plan and monitor instruction and establish a viable classroom culture. From these definitions, one could infer that continuous assessment is an assessment approach which involves the use of a variety of assessment instruments, assessing various components of learning, not only the thinking processes but including behaviors, personality traits and manual dexterity. Continuous assessment will also take place over a period of time. Such an 
approach would be more holistic, representing a learner in his/her entirety. It will begin with decisions that teachers perform on the first day of school and end with decisions that teachers and administrators make on learners, regarding end-of-year grading and promotion.

\section{The Research Method}

The design of this study was a descriptive survey involving both qualitative and quantitative data gathering methods. This method is preferred at it helps the researchers to investigate the current practices and challenges about the issue under study. Further, the use of applying qualitative and quantitative methods simultane- ously is to complement the weakness of one method by the other method.

\subsection{Sample Size and Sampling Techniques}

The study was conducted in three colleges of Teachers' education in the West Oromia Region of Ethiopia, namely: Dambidollo, Shambo and Nekemte colleges of teachers' education, respectively. The sampling includes the graduating class of student -teachers, teachers with ample experiences, vice-deans and deans of colleges of teachers' education. Table 1 shows the summary of sampling stratifications and sampling techniqu from populations of the sampled colleges of teacher edu tion.

Total population, sample size and sampling technique

\begin{tabular}{|c|c|c|c|c|c|}
\hline $\mathrm{S} / \mathrm{N}$ & Sample CTE & Population Name & Population & Sample & plins Technique \\
\hline \multirow{3}{*}{1} & \multirow{3}{*}{ Dambi Dollo CTE } & Regular student- teachers & 1605 & 482 & te. \\
\hline & & Teachers & 61 & 61 & \\
\hline & & Dean and vice dean & 2 & & \\
\hline \multirow{3}{*}{2} & \multirow{3}{*}{ Shambo CTE } & $\begin{array}{l}\text { Regular } \\
\text { Student-teachers }\end{array}$ & & & Systematic random \\
\hline & & Teachers & 43 & & Census \\
\hline & & Dean and vice dean & & & Census \\
\hline \multirow{3}{*}{3} & \multirow{3}{*}{ Nekemte CTE } & $\begin{array}{l}\text { Regular } \\
\text { Student-teachers }\end{array}$ & & 601 & Systematic random \\
\hline & & Teachers & & 74 & Census \\
\hline & & Dean and vice dean & & 2 & Census \\
\hline \multicolumn{3}{|c|}{ Total } & 15 & 1575 & \\
\hline
\end{tabular}

For this study, different data coll ments: questionnaire, interview, classroc ns, ol ati and document review were employed.

Questionnaire: Many scholars wro abo the importance of questionnaire to collec inf $s_{1}$ ation from respondents. [37] states that "aunctior rair is a form, used in survey design that par cipants a study complete and return to the research s." It s means of eliciting beliefs and practices fin viums on the issue under study. In this study, aues nna was the main instrument to collect data rom ac rs and student-teachers.

Interviews: SE i-struc ured face-to-face interviews were used whic allo or further probing of respondents' answ rs [34 Se, i-structured face-to-face intervie $\rightarrow$ pi vide the researchers with the flexibility to slore mo deeply about the practices and challenges o. continuo s assessment and the perception of teachers' educ ors so wards of continuous assessment at the college Therefore, to get additional information and strengthen the data, obtained via questionnaires, the researchers prepared the semi-structured interview of 5 items. The interview was held with deans and vice-deans from each college, regarding the perception of teachers, practices and challenges of continuous assessment at the colleges.

Classroom observation : Observation is a purposeful, systematic and selective way of watching and listening to an interaction or phenomenon as it takes place. There are priate strategy of data collection. Observation helps researchers to get the real behavior rather than elicit reports of preference or intended behavior in the form of selfreport data $[37,38]$. The researchers used this tool to see how teachers practice continuous assessment in their classrooms. This enables the researchers to triangulate the response of a study participant with the real practices of continuous assessment.

\subsection{Data Analysis}

The document analysis started from the inception of the review on Ethiopian education and training policies and practices. The primary focus was on recent documents, updated or originating on the Ethiopian teacher training system, focusing on continuous assessment and the present practices and the significant changes or shifts in the teacher training reform. The initial document analysis provided a base understanding of the factors, driving changes in continuous assessment. All the collected data of using questionnaires and observation checklist were organized and categorized to quantify numerically. Data, generated from the document review, interview and questionnaire, were schematized, while data, generated from FGDs, were narrated. Finally the data from the three colleges of teachers' education were triangulated against the policy documents to draw lessons. Final researchers' experiences led to draw the conclusion of the study and policy implications for future actions. 


\section{Research Results and Discussions 4.1 Presentation of the findings}

As illustrated on Table 2, concerning the sex of teachers participants, about $170(95.5 \%)$ of them were males, whilst $8(4.6 \%)$ were female teachers, participated in the study. As the data of teachers shows that, there was the low proportion of female teachers in colleges of teachers' education, which contradicts with the Ethiopian Education Sector Development Program V (ESDP-V 2016-2020). Furthermore Table 2 por- trayed that teachers' service years were as follows: 61 $(34.3 \%)$ of teachers were between the service year range of $16-20$ and $40(22.5 \%)$ of them were between the experience range of 21-25 year. As well as, the remaining participants, $40(22.5 \%), 14(7.9 \%), 12$ $(6.7 \%)$ and $1(0.6 \%)$ of teachers participants were between the range of $15-15,6-10,>25$ and $1-5$ years of experiences respectively. This implies that the majority of the participants have rich experiences of teaching and learning activity.

Characteristics of the Teachers-respondents by their Sex, age and service year

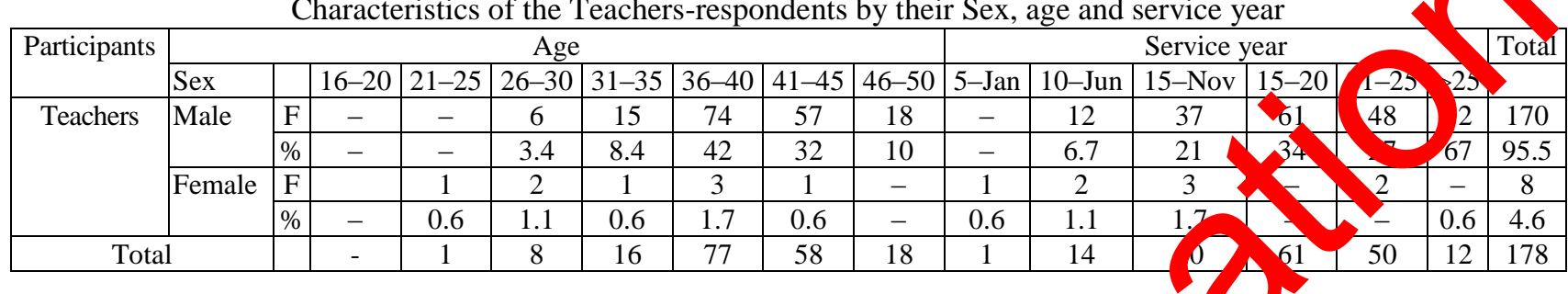

Regarding a teachers' load per week, majority 153 (86\%) of teachers had less than 15 period and $13(7.3 \%)$ of participants had between 15-20 periods and the rest of participants had between 21-25 periods and above 25 periods per week respectively. This indicates that the majority of college teachers have no overload period per week in their regular class. Concerning the educational background of teachers, $28(15.73 \%)$ teachers are first degree holders and $139(78.08 \%)$ of teachers are Master's Degree holders. The rest only $11(6.17 \%)$ of them were diploma holders. This clearly shows that the most of teachers in the colleges are Master's Degree holders with respect to the educational status and require to undertake their activities, relevant to the job, ffer $\mathrm{d}$ t this level.

Furthermore, as shown in Table 3, he stuuent/ class size reveals that majority $162(9 \%$ of theacher participants opined that about 40-59 ud ht sllow their education in a class while the res $(7.5 \%)$ nd $2(1.1 \%)$ of them opined about 60079 at $(30-3)$ students learn in a class respectively.

As Table 4 sho th proportion of studentteachers' sex was al at a alarice since 706 (50.7\%) and 685(49.7) wer male and females respectively. As Table 4 indicatad, age group of the student-teachers participants, about $3 \% \delta(28.3$ and $228(16 \%)$ were range between 21-1 and 16-20 respectively. This shows that th ma, rity student-teachers participants were between $2-25$, ars. Therefore, the age statistics implic th C Im con ges' student-teachers are dominated by the yo nger lo rel.

Table 3

Teach rs' work load, education level and class size

\begin{tabular}{|l|l|c|c|}
\hline \multirow{4}{*}{ Itere } & \multicolumn{1}{|c|}{ Period } & f & $\%$ \\
\hline \multirow{4}{*}{ po wachers' load } & less than 15 per week & 153 & 86 \\
\cline { 2 - 4 } & $15-20$ per week & 13 & 7.3 \\
\cline { 2 - 4 } & $21-25$ per week & 6 & 3.4 \\
\cline { 2 - 4 } & $\begin{array}{l}\text { more than 25 per } \\
\text { week }\end{array}$ & 6 & 3.4 \\
\cline { 2 - 4 } & Total & 178 & 100 \\
\hline \multirow{4}{*}{$\begin{array}{l}\text { Educational } \\
\text { qualification }\end{array}$} & Diploma & 11 & 6.17 \\
\cline { 2 - 4 } & First Degree & 28 & 15.7 \\
\cline { 2 - 4 } & Master's degree & 139 & 78.1 \\
\cline { 2 - 4 } & Total & 178 & 100 \\
\hline \multirow{3}{*}{$\begin{array}{l}\text { Class size } \\
\text { class-student } \\
\text { ratio) }\end{array}$} & $30-39$ students & 2 & 1.1 \\
\cline { 2 - 4 } & $40-59$ students & 162 & 91 \\
\cline { 2 - 4 } & $60-79$ students & 14 & 7.9 \\
\cline { 2 - 4 } & Total & 178 & 100 \\
\hline
\end{tabular}

Note: $f$-frequency

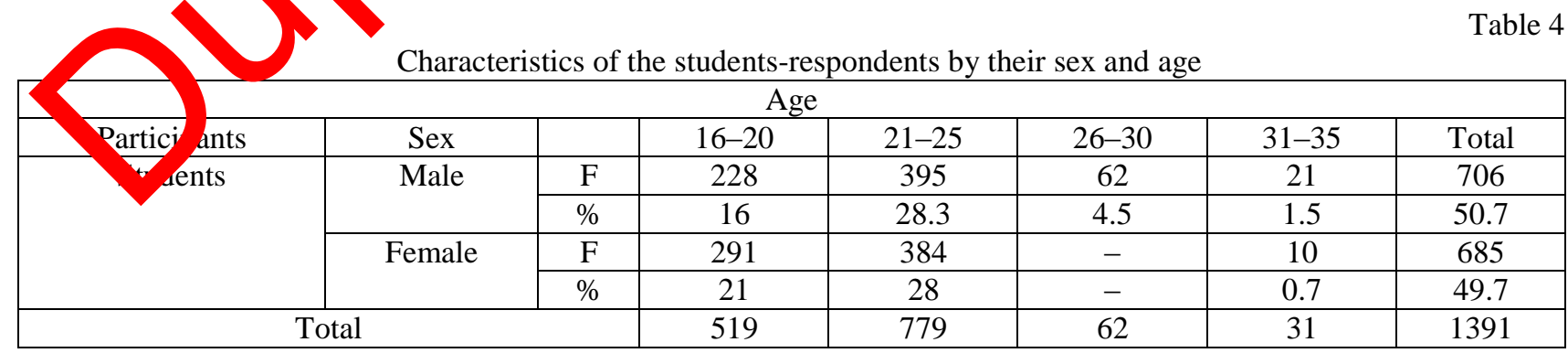

As indicated in Table 5, Item 1, about $8(4.5 \%)$ and $15(8.4 \%)$ of teachers were interrogated daily and every two or three with the frequently practicing of continuous assessment in their instruction. On the other hand, about $67(33.7 \%)$ and $60(15.7 \%)$ of teacher par- ticipants responded once in a semester and twice in a semester with the frequently practicing continuous assessment in their instructions. Beside this questionnaire, the response of the interviewed college vice-dean was given as follows: 
"In our college there is the beginning on practice of continuous assessment, but it is not this much satisfactory because, there are students who has no interest when they are assessed by continuous assessment. Especially, our college students did not like to do assignments and home works. The commitment of our college teachers is also low and there is overlook between our teachers. Due to this I can generalize that currently in our college the technique was not effectively practiced and it needs more effort and works." (Vice-dean W, Date, 02/03/2019)

One of the vice-deans in the college also expressed the response of above as follows:
In our college the practice of continuous assessment is more or less on a good condition and many of our college teachers practice it. But when I say in good condition, I do not mean that there is no limitation on practice of it. Because, there is a degree of variation between our college teachers on dedicating to practice the program and there are factors that hinder them to fully practice continuous assessment. The actual practices of continuous assessment by our teachers were; tests, quiz, oral question, individual and group assignment, the most commonly $y$ assessment methods at the end of each un ( V dean E, Date, 08/03/2019).

Teachers' Practice of Continuous Assessment in Teaching Learning Activ ties

\begin{tabular}{|c|c|c|c|c|c|c|c|c|c|c|c|c|}
\hline \multirow{2}{*}{ Items } & \multicolumn{2}{|c|}{5} & \multicolumn{2}{|c|}{4} & \multicolumn{2}{|c|}{3} & \multicolumn{2}{|c|}{2} & & & \multicolumn{2}{|c|}{ Total } \\
\hline & $F$ & $\%$ & $F$ & $\%$ & $F$ & $\%$ & $F$ & & & & $F$ & $\%$ \\
\hline $\begin{array}{l}\text { Frequent practicing of continuous assess- } \\
\text { ment }\end{array}$ & 8 & 4.5 & 15 & 8.4 & 28 & 15.7 & 60 & & & 37.6 & 178 & 100 \\
\hline $\begin{array}{l}\text { How frequently do you use classwork in the } \\
\text { actual teaching process }\end{array}$ & 9 & 5.1 & 21 & 11.8 & 65 & & & & 52 & 29.2 & 178 & 100 \\
\hline $\begin{array}{l}\text { How frequently do you use oral questions in } \\
\text { your class }\end{array}$ & 59 & 33.1 & 67 & 37.6 & 33 & & & 5.6 & 9 & 5.1 & 178 & 100 \\
\hline $\begin{array}{l}\text { How often do you use class activity in your } \\
\text { class }\end{array}$ & 11 & 6.2 & 22 & & & & 53 & 29.8 & 51 & 28.7 & 178 & 100 \\
\hline $\begin{array}{l}\text { How frequently do you give assignment to } \\
\text { your students }\end{array}$ & 50 & 28 & 58 & & & & 22 & 12.4 & 0 & 0 & 178 & 100 \\
\hline How often do you use tests & 53 & 29.6 & & & & 19.7 & 13 & 7.3 & 15 & 8.4 & 178 & 100 \\
\hline How frequently do you use exams & 51 & 28.7 & 59 & & 43 & 24.2 & 25 & 14 & 0 & 0 & 178 & 100 \\
\hline
\end{tabular}

Note: 5 - Daily, 4 - every 2/3 days, 3 - every week, 2 - Twice in a emer er, 1 -Once in a semester, F-Frequency, \%-Percentage

As indicated in Table 5, Item 2 above abo 9 $(5.1 \%), 21(11.8 \%)$ and $65(36.5 \%)$ of he pa ti par s responded daily, every $2 / 3$ days and eve, wec at the frequency of using class work acti-ity n pectively and about $31(17.4 \%)$ and $52(29.7 \%$, participants responded twice in a semester and on e it a semester with frequently using class wor activity heir classes.

As Table 5 item 3 sho s, ab ut $9(5.1 \%), 10$ $(5.6 \%)$ and $33(18.5$ or he rocipants responded once in a semester, twice a emo ter and every week with frequently using ar ora quo tion in their sessions and about $57(33.1 \%$ and $6(37.6 \%)$ of the participants responded daily nd $2 / 3$ days with frequently using an oral que tion in hein essions to increase the studenttear an ipat on and improve their learning. In the me way in auove Table 5, item 4 above, about 11 (6. \%), $22(12.4 \%)$ and $41(23 \%)$ of the participants resp ded is daily, every $2 / 3$ days and every week with frequen use of class activity in their sessions and about $53(29.8 \%)$ and $51(28.7 \%)$ of the participants responded once in a semester and twice in a semester with the frequently use of class activity in their sessions to increase the student-teachers' participation and improve their learning.

As Table 5 item 5 shows, about $22(12.4 \%)$ and $48(27 \%)$ of teachers responded twice in a semester and every week with frequently giving assignments to their students and the rest about $58(32.6 \%)$ and 50 (28\%) of participants responded as every $2 / 3$ days and daily with froquently giving assignment to their students in their schools. Table 5 item 6 reveals, about 13 (7.3\%), 15 $(8.4 \%)$ and $35(19.7 \%)$ of the participants responded twice in a semester, once in a semester and every week with frequently using tests to measure the students' learning performance respectively and the rest about 62 $(34.8 \%)$ and $53(29.6 \%)$ of the participants responded every $2 / 3$ days and daily with frequently using tests to measure the students' learning performance. Similarly to this idea, one of the college deans also expressed the response and pointed out that:

"Our teachers did not encourage student-
teachers to participate
during teaching and learning and they teach
them without giving chance for students and
they run fast to cover the portion only and
our teacher gave tests and assignment many
times, especially this year our teacher was
giving at least one tests per three week and
one assignment per a month. During this year
our teachers used different assessment such
as assignment, quizzes, written tests and oth-
ers instead of using single mid examination."
(Vice-dean M, Date 05/03/2019)

From these participants it is possible to deduce that even if college teachers use different assessment techniques, there was somewhat limitation by the teachers on using different assessment techniques to measure 
the students' achievement. This means, since continuous assessment involves the use of great values of modes of evaluation for the purpose of guiding and improving the learning and performance of students, the teachers are required to use different mode effectively for the benefit of the learners.

As indicated in Table 5, most of the college teachers use an oral question, assignment, test and exam as the most frequently used assessment technique. Therefore, from this one can infer that most of the College teachers make use of limited continuous assessment techniques rather than finding alternative methods to reach all the students. Supporting this, Brown, Bull, and Pendlebury (1997) advised that if essays are used as the only form of assessment, students' writing may improve, but other skills may remain undeveloped. In the same way, NOE (2004) explained that evaluation of students' acquisition of knowledge and skills is an integral part of the teaching learning processes and continuous assess- ment is an assessment approach that involves the use of a variety of assessment instruments to assess various components of learning.

As Table 6 describes responses by studentteachers on the extent of continuous assessment, practiced by their teachers in class teaching, accordingly, item 1 describes about 239 (17.2\%), 197 (14.2) \% and $83(5.9 \%)$ of the participants, responded 2-3 day, once in a semester and daily with the frequency of teachers' giving a class work, while the rest $498(35.8 \%)$ and $374(26.9 \%)$ of student-teachers responded as every week and twice in a semester with the frequency of teachers' cond -ing a class work in their colleges.

As above Table 6 item 2 shows. at ut 170 $(12.7 \%)$ and $73(5.2 \%)$ of participants a reen and 2-3 day with teachers' frequently givin a pra ical activity for their students and the rest ou ref $(49.3 \%)$ and $457(32.8 \%)$ of them respor as a ce in a semester and twice in a semester rec tive with the idea.

Table 6 Student-teachers' practice of Continuous Assessment in Teaching-I earning wrivities

\begin{tabular}{|c|c|c|c|c|c|c|c|c|c|c|c|c|}
\hline \multirow{2}{*}{ Items } & & 5 & 4 & & 3 & & & & \multirow{2}{*}{$\frac{1}{\mathrm{~F}}$} & \multirow[b]{2}{*}{$\%$} & \multicolumn{2}{|c|}{ Total } \\
\hline & $\mathrm{F}$ & $\%$ & $\mathrm{~F}$ & $\%$ & $\mathrm{~F}$ & & & & & & $\mathrm{~F}$ & $\%$ \\
\hline $\begin{array}{l}\text { How frequently do your teachers } \\
\text { give you class work in your class }\end{array}$ & 83 & 5.9 & 239 & 17.2 & & & & 26.9 & 197 & 14.2 & 1391 & 100 \\
\hline $\begin{array}{l}\text { How frequently do your teachers } \\
\text { give you practical activities }\end{array}$ & - & - & 73 & 5.2 & & & 457 & 32.8 & 685 & 49.3 & 1391 & 100 \\
\hline $\begin{array}{l}\text { How frequently do your teachers } \\
\text { give you a home work }\end{array}$ & 145 & 10.5 & 323 & & & & 249 & 17.9 & 73 & 5.2 & 1391 & 100 \\
\hline $\begin{array}{l}\text { How frequently do your teachers ask } \\
\text { you an oral question in the class }\end{array}$ & - & - & & & 997 & 71.6 & 260 & 18.7 & 41 & 3 & 1391 & 100 \\
\hline $\begin{array}{l}\text { How frequently do your teacher ob- } \\
\text { serve your work }\end{array}$ & 197 & & & & 426 & 30.6 & 332 & 23.9 & 156 & 11.2 & 1391 & 100 \\
\hline $\begin{array}{l}\text { How frequently do your teacher as- } \\
\text { sess your performance with a project } \\
\text { work }\end{array}$ & & & & 12.7 & 270 & 19.4 & 426 & 30.6 & 519 & 37.3 & 1391 & 100 \\
\hline
\end{tabular}

Note: 5 - Daily, 4 - every two or three days $3-7$ week, 2 - Twice in a semester, 1 - Once in a semester, $F$ - Frequency,

$\%$ - Percentage

As shown in Table 6 ite $n$, al but 249 (17.9\%), $145(10.5 \%)$ and $73(1 \%$ \% pants agree twice a seme r, o ily and once in a semester with how freque ary tea ers give a home work for students to streng en the knowledge from their class and the rest $6,(43, \%)$ and $323(21 \%)$ of studentteachers participa s op ed as every week and 2-3 day witb fro uentl Meachers give a home work for stud its. In me wole 6, item 4, about $41(3 \%)$ and 93 ( $7 \%$ ) of tudents responded once in a semester and eve $2 / 3$ ys with how frequent teachers ask their students a oral question and the rest $997(71.6 \%)$ and 260 (18.7\%) of student-teachers responded every week and once in a semester with how frequent teachers ask their students an oral question to see and examine their understanding about the topic of their learning.

As indicated in Table 6 item 5, about 280 (20.1\%), $197(14.2 \%)$, and $156(11.2 \%)$ of participants responded 2-3 day, daily and once a semester with how frequent teachers observe the work of their students in the class respectively and the rest $426(30.6 \%)$ and $332(23.9 \%)$ of participants responded every week and twice a semes- ter with how frequent teachers observe the work of their students in the class. Same Table 6 item 6 indicated that about $270(19.4 \%)$ and $176(11.9 \%)$ of student-teachers responded as every week and 2-3 day with how frequently teachers assess the student-teachers' performance by giving a project work and the rest 519 (37.3\%) and 426 $(30.6 \%)$ of student-teachers responded twice a semester and once a semester with how frequently teachers assess the student-teachers' performance by giving a project work.

One of the vice-deans in the college E also confirmed the response of students and said that:

"Our teachers did not encourage students to participate during teaching and learning and they teach without giving chance for students and they run fast to cover the portion only. Again our teachers do not identify the level of students and the measures of students by preparing questions which we are not learned in the class."(Date 01/04/2014).

As the result of an analysis shows, the majority of student-teachers confirmed that their teachers are not 
fully practicing the continuous assessment activities. From this one can infer that the majority of teachers use similar assessment techniques.

Regarding continuous assessment, the mark list was properly analyzed and important notes were taken from three colleges of Teachers Education' in 2011/2018/9 academic year and 36 achievement record sheets were investigated. The mark lists of continuous assessment contain the variety of assessment techniques as individual assignment, group assignment, quiz, test, mid exam and final exam. According to Table 7, a teacher used only few places of mark lists to fill a students' mark. Table 7 depicts that a quiz, test, exam and assignments are used as continuous assessment techniques in colleges of teachers' education. The document review was made to validate or identify the consistency of the questionnaire with the actual teachers' practice, given for the subject, included in the study.

Finally, the researchers observed that most of the assessment formats were not appropriate to record every activity of the learners. Because, the space, given to the assessment format, was more convenient to record terminal assessments i.e.: test, quiz, mid exam and final exam than different types of assessment. From this one can conclude that the majority of teachers use similar assessment techniques and they have basic skill of recording and documenting students' continuous ass ment achievements. The actual practices of contin lous ssessment by teachers: quiz, test, exam, indivi al and group assignment were the most commo $4 \mathrm{y} \mathrm{u}_{\mathrm{n}} \mathrm{d}$ a cessment methods.

Issues, analyzed in the student mark list format

Table 7

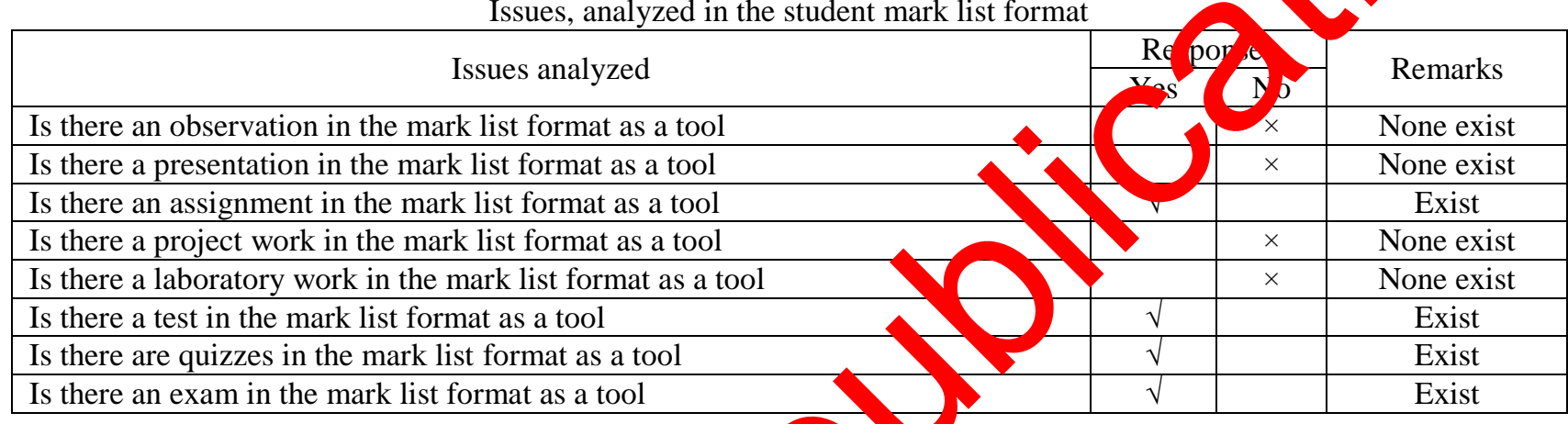

of ontinuous Assessment Practices

Table 8

Teacher's Perception towards Problen of ontinuous Assessment Practices

\begin{tabular}{|c|c|c|c|c|c|c|c|c|c|c|c|c|}
\hline \multirow{2}{*}{ Items } & & & & & \multicolumn{2}{|c|}{ UD } & \multicolumn{2}{|c|}{$\mathrm{D}$} & \multicolumn{2}{|c|}{ SD } & \multicolumn{2}{|c|}{ Total } \\
\hline & & & & & $\mathrm{F}$ & $\%$ & $\mathrm{~F}$ & $\%$ & $\mathrm{~F}$ & $\%$ & $\mathrm{~F}$ & $\%$ \\
\hline Class size & & & 5 & 30.9 & 16 & 9 & 34 & 19 & 10 & 5.6 & 178 & 100 \\
\hline Teachers negative attitude on CA & & & 6 & 3.4 & 19 & 10.7 & 83 & 46.6 & 55 & 30.9 & 178 & 100 \\
\hline Shortage of time & & & 109 & 61.2 & 31 & 17.4 & 4 & 2.2 & 12 & 6.7 & 178 & 100 \\
\hline Lack of awareness/knowledge & & & 13 & 7.3 & 81 & 45.5 & 49 & 27.5 & 13 & 7.3 & 178 & 100 \\
\hline Shortage of teaching materials & & 6.2 & 31 & 17.4 & 51 & 28.7 & 71 & 39.9 & 14 & 7.9 & 178 & 100 \\
\hline Teachers' workload & 51 & 28.7 & 77 & 43.3 & 17 & 9.6 & 2 & 1.1 & 31 & 17.4 & 178 & 100 \\
\hline Low interest of studen & 48 & 27 & 52 & 29.2 & 27 & 15.17 & 25 & 14 & 26 & 14.6 & 178 & 100 \\
\hline large instructional conte & 33 & 18.5 & 74 & 41.6 & 53 & 29.8 & 6 & 3.4 & 12 & 6.7 & 178 & 100 \\
\hline lack of commitmen am ng ache & 42 & 23.5 & 48 & 26.9 & 34 & 19.1 & 30 & 16.8 & 24 & 13.5 & 178 & 100 \\
\hline
\end{tabular}

Note: SA-strong gree, - Agree, UD-Undecided, D-Disagree, SD-strongly disagree, $f$-Frequency, \%-Percentage

The data in Tab 8 depicts MAJOR FACTORS, infly ing pra trce or continuous assessment in coles of to herducation.

Clas size: to express deliberately how large class sizo ffecto he practice of continuous assessment, about $63(3, \%)$ and $55(30.9 \%)$ of the teachers opined as strongly agree and agree with the class size problem. Related to this idea, one of the college vice-deans said as follow:

"It is very difficult to manage more than 50 students in a single class and come up with an effective practice of continuous assessment. Had there been less number of students, it would have been manageable for continuous assessment to be fully practiced."

(Dean E, Date, 08/03/2019)
In connection with this idea, [34] contended that the problem of large class size is very serious to assess the student's class work and homework. Similarly, - [7, 39] indicated that a large class size is the most limiting problem that affects the implementation of continuous assessment.

Shortage of time: Table 8 indicates that about $109(61.2 \%)$ and $22(12.4 \%)$ of participants opined as agree and strongly agree on time constraint as a continuous assessment practice.

Regarding to this, one of the interviewed vicedeans points out:

"Teachers are offering many different courses per semester. Furthermore, they are expected to complete the course, from which they are assigned, to offer according to the 
schedule, given to them by the office of the registrar. In additional to this, they are doing practicum part I up to IV and they are correct practicum portfolio and take reflection. This makes them busy." (Vice-dean W, Date, 02/03/2019).

Interest of students: As could be observed from above, the majority of participants had the perception that time was one of the constraints; Table 8 item 8 indicated about $48(26.96 \%)$ and $52(29.21 \%)$ of teacher respondents, opined as strongly agree and agree with the low interest of students as a problem, affecting the practice of continuous assessment. The College Dean had the following to say, regarding the low interest of students:

Most student-teachers are not familiar with the newly developed continuous assessment program. They were accustomed to taking mid, final and national entrance exams, when they were at secondary school. Hence, here at the college level, when teachers tell them that they had finished their evaluation out of sixty per cent in the classroom, they complain their dissatisfaction and even sometimes they were seen to be shocked by the information from the teacher (Dean $\mathrm{M}$, Date, 05/03/2019).

The majority of respondents accepted that the low readiness of students influenced teachers not to fully practice continuous assessment as effectively as possible.

Teachers' work load: Table 8 item 6 indicated that about 17 (9.6\%) of them also responded as undecided about the teachers' work load as a problem, affecting the continuous assessment practice in their colleges respectively and about $77(43.3 \%)$ and 51(28.7\%) of th chers confirmed that agree and strongly agree wit the $^{\text {the }}$ teachers' work load as a problem, affectiv the ract' e of continuous assessment in their classes. line with this, one of the interviewed college de as intemut:

"Our teachers are offering ho y ferent courses per semester. ost of an college teachers teach move tho four ourses, especially, Educann nec. nd language stream have a lon oj lifferent courses. In addition to th ch are doing practicum, involving diffe, nt committees, teaching night an we kend program. Therefore, they run in sho, ge time to practice continuous rses rent s ncessyully. As a result, it is easy to agt low challenging them each course throu h continuous assessments is." (Dean W, Date 15/03/2019)

Large instructional content: Table 8 item 8 indicated about $33(18.5 \%)$ and $74(41.6 \%)$ of teacher participants, opined as strongly agree and agree with the large instructional content as a problem, affecting the practice of continuous assessment. Regarding to this, one of the interviewed vice-deans pointed out:

"The credit hour given and subject content is mismatched in many courses and teachers are not covering the portion of lesson on time. For this reason teachers are run for cover of portion rather than practice continuous assessment." (Vice dean M, Date, 04/03/2019)

In line with these facts the most commonly mentioned challenge to implement continuous assessment is insufficient time allocation for the course.

Lack of commitment among teachers: According to Table 8, about $48(29.96 \%)$ and 42 $(23.59 \%)$ of participants very claim as agree and strongly agree with the lack of commitment among teachers as a problem, affecting the continuous assessment practice in their learning activities.

In line with this, one of the college vi e-dea said as follow:

"Currently the criteria for promo on, an. fer and training are not cear r mar of teachers. Someone can b give, $a-$ position because of friendsh, or lo, years of teaching experience, y.u tho reachers who have shown a $h \mathrm{~h}$ of officiency and performance in togch g. nis makes them less committed (V W, ate, 02/03/2019)

It can be conc ded, at a class size, shortage of time, interest ft. 'enı, cachers' work load, large instructional cont t a lack of commitment among teache a e th ma $r$ factors that influence the practice of contin us as ssment in a college of teachers' education.

A revealed in Table 9, the majority of participants $34524.6 \%)$ and $570(41 \%)$ participants responded as as e and strongly agree with the class size problem. Table 9 it $\mathrm{m} 3$ indicated that about $249(17.9 \%)$ and $654(47 \%)$ student-teachers responded as agree and strongly agree th the time constraint is one of problem impacts of the continuous assessment practice. In the same manner, about $353(25.4 \%)$ and $405(29.1 \%)$ of student-teachers responded as agree and strongly agree with the teachers' work load as a problem, affecting the practice of continuous assessment in their classes.

Accordingly, most of the student-teachers confirmed that a class/students size, shortage of time, and heavy work load were identified as a major problem, affecting the practice of continuous assessment in their colleges.

A college vice-dean had the following to say regarding the challenges of continuous assessment:

"The teachers have the necessary skills of recording and documenting students' continuous assessment achievements. But the main problem is large numbers of students in the class, shortage of time, high loads of many courses and low interests of students, which are an obstacle to practice continuous assessment properly." (Vice-dean E, Date, 08/03/2019).

Generally, according to the data processed, the most serious factors, affecting the practice of continuous assessment are: Class size, Shortage of time, Low readiness of students, Teachers' work load, Large instructional content and Lack of commitment among teachers. These major factors influence the practice of continuous assessment in their learning activities 
Student-Teachers' Perception on Continuous assessment Practices

\begin{tabular}{|l|c|c|c|c|c|c|c|c|c|c|c|c|}
\hline \multirow{2}{*}{ Items } & 5 & & 4 & & 3 & & 2 & & 1 & & Total & \\
\cline { 2 - 14 } & $\mathrm{F}$ & $\%$ & $\mathrm{~F}$ & $\%$ & $\mathrm{~F}$ & $\%$ & $\mathrm{~F}$ & $\%$ & $\mathrm{~F}$ & $\%$ & $\mathrm{~F}$ & $\%$ \\
\hline Class size & 343 & 24.6 & 570 & 41 & 125 & 9.0 & 322 & 23.1 & 31 & 2.2 & 1391 & 100 \\
\hline Teachers attitude on CA & 52 & 3.7 & 187 & 13.4 & 882 & 63.4 & 218 & 15.7 & 52 & 3.7 & 1391 & 100 \\
\hline Shortage of time & 654 & 47 & 249 & 17.9 & 114 & 8.2 & 218 & 15.7 & 156 & 11.2 & 1391 & 100 \\
\hline Knowledge problem & 145 & 10.4 & 21 & 1.5 & 207 & 14.9 & 436 & 31.3 & 581 & 41.8 & 1391 & 100 \\
\hline Education aid problem & 197 & 14.2 & 93 & 6.7 & 561 & 40.3 & 343 & 24.6 & 197 & 14.2 & 1391 & 100 \\
\hline $\begin{array}{l}\text { Problem of teachers insufficient } \\
\text { preparation }\end{array}$ & 342 & 24.6 & 125 & 9 & 52 & 3.7 & 478 & 34.3 & 394 & 28.4 & 1391 & 100 \\
\hline Heavy work load of teachers & 353 & 25.4 & 405 & 29.1 & 197 & 14.2 & 208 & 14.9 & 228 & 16.4 & 1391 & 100 \\
\hline Lack of support from the collegefor & 322 & 23.1 & 218 & 15.7 & 561 & 40.3 & 145 & 10.4 & 145 & 10.4 & 1391 \\
\hline
\end{tabular}

\subsection{Discussion of Results}

\subsubsection{Teachers' Perception towards Continuous} Assessment

The finding revealed that teachers have a positive perception and understanding about continuous assessment. The finding from this study is similar to that of [40] on the teachers' perception and practices towards continuous assessment that states that teachers have a positive perception and understanding about continuous assessment. In relation to this, [4] suggested that teachers' knowledge and attitude should be considered for the effective implementation of the assessment program. According to the response, obtained from questionnaires of teachers and interview of deans and vice-deans, most of teachers have a positive perception and understanding about continuous assessment. A new continuous assess ment program can succeed only if teachers accept it. If teachers do not accept the philosophy of this program, it is clear that it is not possible to implement the $109 \mathrm{~m}$. Accordingly, [4] strengthened this idea and uo ost t that teachers must understand the asses ant os, feel secure about it, and accept it as th ow for its effective implementation.

The result, obtained from the in ervi w of deans and vice-deans shows that teac ers hav basic skill of recording and documenting st tents ontinuous assessment achievements. $\mathrm{N}$ st th also accepted that teachers prefer continuou ass sment than mid exams and final exams. In caan of this, most of the respondents accepted and lievec that continuous assessment is necessary to in easo the academic achievement of students, solv stude s le ning problems, and continuous asse th a variety of assessment techniques. In 1. with $\mathrm{s}$, s, $[4+1]$ states that continuous assessment is a $g$ eral tern that includes the full range of procedures, used ga information about students learning (observation, ang of performance, or projects, paper and pencil tests) and the formation of a value judgment, concerning the learning progress.

\subsubsection{Practices of Continuous Assessment}

This study also came up with findings that are consistent with other previous research findings in contrary to that of $[10,40,42-44]$, indicating that there was a low practice of continuous assessment in colleges of teachers' education. In this study, the results, concerning the current practice of continuous assessment, suggest that it is possible to deduce the hardly ossibl way of continuous assessment practices 'a a legu teachers' education. The finding, obtainea $m$ to chers and students, shows that the teache a d a type of continuous assessment tools, su h signments, quizzes, tests, mid and final ex? are or nating the rest. Moreover, the findings re ealed hat most of teachers used similar contimuou as ssme its. In spite of this, it was found out, th. as ssment methods, most frequently used, were accigh ent, quizzes tests and final examination. T. fina $g$ agree with [43], which found out that teachers a not $y$ e various assessment methods to check the pup's h rery of the desired knowledge, skills and a tudes, yt rather focus mostly on written tests and om vo

The results from the observation checklist also indic ted that the majority of teachers were not familiar to re oral questions, to use a variety of continuous assessmont tools, to give information about continuous assessment, encourage students to assess their own work and others' work. In addition to this, the interview and the document analysis result as well showed that teachers mostly used assignments, quizzes, tests, and exam. But, project and field works were not used as tools of assessment. In line with this [10], observed that the actual practices of continuous assessment by teachers were: exams, tests, quiz, individual and group assignment. They were the most commonly used assessment methods at the end of each unit. This finding indicates that instruments for assessing the cognitive domain were highly used by the teachers and they were most often used for assessing students' knowledge of content.

The instruments for assessing the affective and psychomotor domains were less used. This was not satisfied the definition of continuous assessment as stated by [35]. Regarding to this [45], found that the current continuous assessment system gives no attention to a project work, which is the most important learning medium that allows pupils to take active part in their own learning.

\subsubsection{The Major Factors that Influence the Practices of continuous assessment}

The study revealed that the major factors, affecting the practices of continuous assessment are: class size, shortage of time, interest of the students, teachers' work load, large instructional content and lack of commitment among teachers. 
A class size concerns with learning to occur positively when lessons are under appropriate conditions both for a teacher and students. Similarly [34] contended that the problem of large class size is very serious to assess a student's class work and homework. Teachers, who teach many students in an overcrowded classroom, often say that it is certainly not suitable to provide activities for such classes. In line with this, [36] states that teachers commonly complain that the class-size is hampering their attempt at practicing continuous assessment and recording each and every student's performance. The study shows that there is a poor classroom condition which is not suitable to practice continuous assessment in a classroom. The data, gathered from the questionnaire and interview, shows that the numbers of students in class are large and so it is difficult to evaluate, manage, and practice continuous assessment as the intended whole.

Concerning challenges of continuous assessment, most of the respondents of teachers also accepted Class size, Shortage of time, Low interest of students, Teachers' work load, Large instructional content and Lack of commitment among teachers as the major factors that influence the practice of continuous assessment in their learning activities. In addition to this, the result of the deans' and vice-deans' interview also showed that a Class size, Shortage of time, Low interest of students, Teachers' work load, Large instructional content and Lack of commitment among teachers were the major factors, affecting the practice of continuous assessment in their colleges.

According to [46], it was observed, that teachers fail to use continuous assessment in the classroom due to the following challenges.
These are:

a) large class size,

b) lack of commitment,

c) broad course content.

The successful implementation of continuous assessment demands more work time and responsibility on the part of teachers. As could be observed from the data, the participants had the perception that time was one of the constraints, which influenced them not to fully implement continuous assessment as effectively as possible. Among the factors that were identified hindering the implementation of continuous assessment is the lack of commitment b- pachers. From the data, gathered from deans' and re-de. 's' complaining, teachers are overloaded with many courses. As a result, teachers are expected to con oleto he ourse from which they are assigned to offer ccordi s to the schedule. This makes teachers foc on ster cover than use of continuous assessment

\section{Conclusions}

Based on the abour fin ing of the study, the following conclusions w re draw

- The continud s ass ssment practice at Teacher Education Co eges in western Oromia region of Ethiopia is ineffo ive $\mathrm{d}$ null practiced.

The dy also revealed that though college teachers hibite the positive perception, they are unable to npl an or practice continuous assessment bec use of weekly workload.

-7 he finding disclosed that a large class size, shortas of time, teachers' work load, low interest of students, lar instructional content and lack of commitment among achers are the major factors, hindering the practice of conth. ous assessment in colleges of teachers' education.

1. Transitional Government of Eth pita TGE References ation and Training Policy. Addis Ababa, 1994.

2. MoE. Education and Training I lic A dis Ababa: Educational Materials Production, 1994.

3. Brown G. T. L. Teachers' cep on o assessment: implementation for policy and professional development, university of Auckland, New Zealand // Assessme t Eduçtion. 2004. Vol. 11, Issue 3. P. 301-318. doi: http://doi.org/10.1080/0969594042000304609

4. Teshome D. Assessment f pup s' achievement in the teaching English: Training and practice in focus // The Ethiopian Journal of Education. 200 Vol. XXi, de 1. P. 25-40.

5. USAID/BEP. A co vise anual for developing and implementing continuous assessment in teacher education institutions and primary schools Addis Ababa: Academy for educational Development (AED) in consortium with Ministry of Education (MOE), 2" 6.

6. Apple 4., S imo Learners to Teacher: Portfolio Please! Perceptions of Portfolio Assessment in EFL Classroom, 2004. URL: http://hosted., lt.or vansig/2004/HTML/AppleShimo.htm

7. Eh gton 5 Earı. Making Effective Use of Continuous assessment and Portfolios, 1997.

\section{ap://doi.or 10.4324/9780203062036}

9. Li) hgston. Taking Teacher Educators Forward: Ten Steps towards Quality-A report. TEMSD: MOE, 2001.

10. etinet S. Assessment of the Implementation of Continuous Assessment: the case of METTU university // European Journal science and Mathematics Education. 2016. Vol. 4, Issue 4. P. 534-544.

11. Greaney V., Kellaghan T. Using Assessment to Improve the Quality of Education. Paris International Institute for Educational Planning, 2001. 98 p.

12. Ertmer P. A., Newby T. J. Behaviorism, Cognitivism, Constructivism: Comparing Critical Features from an Instructional Design Perspective. Performance Improvement Quarterly. 1993. Vol. 6, Issue 4. P. 50-72. doi: http://doi.org/10.1111/j.19378327.1993.tb00605.x

13. Ipaye T. Continuous Assessment in Schools (With Some Counseling Applications. Ilorin: Ilorin University Press, 1982.

14. Lewis A. C. Changing assessment, changing curriculum // Education Digest, 1997. P. $12-17$.

15. Ugodulunwa C. A. Crisis Continues Assessment Practices: Challenges for Measurement Expert // Journal of Science and Education Forum. 1996. Vol. 1, Issue 1. P. 86-92.

16. Airasian P.W. Classroom Assessment. New York: McGraw-Hill, Inc., 1994.

17. Miller P. H. Theories of developmental psychology. New York: Worth Publishers, 2005. 507 p.

18. Nitko J. A. Educational Assessments. Englewood: Prentice-Hall, Inc., 1996. 487 p. 
19. Madaus, Kellagan Basic Concepts of Continuous Assessment. New York: Magraw- Hill.Inc., 1993.

20. A Developmental Perspective on Standardized Achievement Testing / Paris S. G., Lawton T. A., Turner J. C., Roth J. L. // Educational Researcher. 1991. Vol. 20, Issue 5. P. 12-20. doi: http://doi.org/10.3102/0013189x020005012

21. Mercy K. Assessment Problems in Zimbabwe's Primary Schools with special reference to Gweru district schools: Doctoral Dissertation. Zimbabwe: Open University, 2012. 360 p.

22. Kapambule W. The Implementation of School Based Continuous Assessment (CA) in Zambia // Education research and reviews. 2010. Vol. 5, Issue 3. P. 99-107.

23. Takele A. The state of continuous assessment practices in secondary schools of Oromia special Zone: Challenges and prospects. Addis Ababa, 2010.93 p.

24. MOE. Guidelines for Continuous Assessment. Ethiopia: Addis Ababa, 2004.

25. Puhl C. A. Develop, Not Judge: Continuous Assessment in the ESL classroom // Forum Online. 1997. Vol. 35, Issue 2. URL: https://eric.ed.gov/?id=EJ593288

26. Reece I., Walker S. Teaching, Training and Learning: A Practical Guide. Sunderland: Business Education Publishers Ltd, 2003. 438 p.

27. Muluken A. Teachers Perception and practice of Continuous assessment in Selected Government first cyd primar school: MA Thesis. Addis Ababa, 2006.

28. Harris M. Self-assessment of language learning in formal settings // ELT Journal. 1997. Vol. 51 Issue 1. P. 1-20. doi: http://doi.org/10.1093/elt/51.1.12

29. Brown G., Bull J., Pendlebury M. Assessing Students Learning in Higher Education. Londd Mou dg , 336 p. doi: http://doi.org/10.4324/9781315004914

30. Spandel Stiggins. Assessment and Evaluation. Evaluation, 1990.

31. Martin J. Elementary Science Methods: A constructive Approach. Delmar Publishers, 1

32. Gensee F., Upshure A. Classroom Based Evaluation in Second Language Education. Canmb dge Cambridge University Press, 1996. 268 p.

33. Struyven K., Dochy F., Janssens S. Student's Perceptions about ass smer in H her Education. 2002. URL: http://www.leeds.ac.uk/educol/documents/00002255.htm

34. Hayes D. Helping teachers to cope with large classes // ELT Journa 199 Vol. 51, Issue 2. P. 106-116. doi: http://doi.org/10.1093/elt/51.2.106

35. Obioma G. Educational Assessment in the Culture of Reform CO te // Pa er vesented at the 31St Annual Conference of the International Association for Educational Assessment (IAEA) held at the icon $\mathrm{H}$ ton Hotel. Abuja, 2005.

36. Tesfaye S. Continuous Assessment in Teacher Education Prog ms: ng the Experience of Debub University. A paper presented on national workshop on continuous assessment. Addis Ababa, 005.

37. Creswell J. Educational research: Planning, conducting, an eval kating, conducting, and evaluating quatitative and qualitative research. Bosten: Person Education, Inc, 2012. 673 p.

38. Yin R. K. Qualitative Research from Start to Finish. ew Yo. The Guilford Press, 2011.

39. Papworth H. A VSO CPD Advisors View of Contin us ssessment in Ethiopia. A paper Presented to the National Workshop on Continuous Assessment organized by AED/BESO. Adu Ababa, 2005.

40. Temesgen S. Teachers' Perception and Pr ato to wards Qntinuous Assessment of Mathematics Classes: The Case of Secondary School in Wolaita Zone, Snnpr Region //. ur al Education and Practice. 2017. Vol. 8, Issue 22.

41. Linn R. L., Miller M. D. Measureme, and sess nt in teaching. Upper Saddle River: Merrill/PrenticeHall, 2005. 550 p.

42. Argall M. W. Ideology and the curricur n. New York: Rout! Ooge, 2001.

43. Berihu A. Implementation of Con uou. Assessment and Its Effectiveness in Adwa College of Teacher Education, Ethiopia // International Journal of Educa on cur re and Society. 2016. Vol. 1, Issue 1. P. 16-22.

44. Black P., Wiliam D. Insirhe E ack box: Raising Standards through Classroom Assessment // Phi Delta Kappan. 1998. Vol. 80, Issue 2. P. 139-144

45. Quansha K. Contin wous ssessn ent hand book. 2005.

46. Abera A. Con uou Assu ent (Ca) Vis-À-Vis the Attainment of Major Educational Domains of Physical Education in Ethiopia // International Jo nal Social Science \& Interdisciplinary Research. 2012. Vol. 1, Issue 11. P. 14-27.

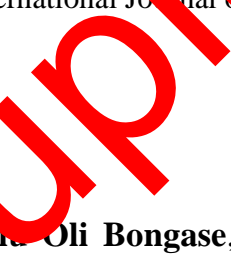

Received date 21.01.2020

Accepted date 14.02.2020

Published date 25.05.2020

Ge achu Oli Bongase, Graduate student, College of Education and Behavioral Science, Jimma University, Dam idoollo College of Teachers Education, P.O. Box 395, Nekemte, Ethiopia

Em 1: Gemechuoli@gmail.com

Teklu Tafase Olkaba, PhD, Assistant Professor, Comparative and International Education, College of Education and Behavioral Science, Jimma University, P.O. Box 395, Nekemte, Ethiopia

Email: teklu252@yahoo.com 